\title{
Analysis of Prehistoric Artifacts from 2003 Excavations at the George C. Davis Site (41CE19), Cherokee County, Texas
}

Timothy K. Perttula

Heritage Research Center, Stephen F. Austin State University

Follow this and additional works at: https://scholarworks.sfasu.edu/ita

Part of the American Material Culture Commons, Archaeological Anthropology Commons, Environmental Studies Commons, Other American Studies Commons, Other Arts and Humanities Commons, Other History of Art, Architecture, and Archaeology Commons, and the United States History Commons

Tell us how this article helped you.

This Article is brought to you for free and open access by the Center for Regional Heritage Research at SFA ScholarWorks. It has been accepted for inclusion in Index of Texas Archaeology: Open Access Gray Literature from the Lone Star State by an authorized editor of SFA ScholarWorks. For more information, please contact cdsscholarworks@sfasu.edu. 


\section{Analysis of Prehistoric Artifacts from 2003 Excavations at the George C. Davis Site (41CE19), Cherokee County, Texas}

\section{Creative Commons License}

\section{(c) (1) \&}

This work is licensed under a Creative Commons Attribution-NonCommercial 4.0 International License 


\title{
Analysis of Prehistoric Artifacts from 2003 Excavations at the George C. Davis Site (41CE19), Cherokee County, Texas
}

\author{
Timothy K. Perttula
}

A small sample of artifacts were recovered in 2003 archaeological excavations at the George C. Davis site (Caddoan Mounds State Historic Site) by The University of Texas at Austin (Table 1). The work was done in conjunction with a large-scale geophysical survey of the site to locate archaeologically significant geophysical anomalies (i.e. Caddo structures, pit features, palisades, burial features, etc.) (Creel et al. 2005; Walker 2009). The excavations in Unit 113, ca. 150 m east of Mound B (Figure 1), were focused on Feature 237, a kind of circular Caddo structure called a "Button House" (Schultz 2010) because of its four support posts around a central hearth feature.

The principal kinds of artifacts found in the work include plain and decorated Caddo pottery sherds (40\%), lithic debris (27\%), and small pieces of what appears to be a glauconitic-rich clay (18\%)

Table 1. Recovered artifacts from 2003 excavations at the George $C$. Davis site.

\begin{tabular}{lc}
\hline Artifact Category & No. \\
\hline Burned clay & 2 \\
Daub & 1 \\
Glauconitic-rich clay pieces & 10 \\
Decorated ceramic sherds & 4 \\
Plain ceramic sherds & 18 \\
Chipped stone tool fragment & 1 \\
Lithic debris & 15 \\
Lithic chunks/cores & 3 \\
Iron cut nail & 1 \\
\hline$\quad$ Totals & 55 \\
\hline
\end{tabular}

that are likely not naturally found in the soils at the site. Appendix 1 provides an inventory, by provenience, of the recovered artifacts.

Four of the 22 sherds $(18.2 \%)$ have decorations. One small rim from the plow zone has a single horizontal engraved line on it, while a body sherd from the same context may be from a Dunkin Incised vessel with opposed incised lines on the rim or upper portion of the vessel body (see Suhm and Jelks 1962:Plate 19). Feature 237-1 has a body sherd from a Kiam Incised vessel (see Suhm and Jelks 1962:Plate 45b-c, e) with at least four rows of tool punctates on the vessel body. The last decorated sherd is from a well-made and well burnished Holly Fine Engraved deep bowl with a engraved decoration consisting of sets of fine engraved lines running vertically and horizontally in different decorations (see Suhm and Jelks 1962:77 and Plate 40f), with small triangular-shaped excised areas attached to at least four sets of vertically-arranged engraved lines. Holly Fine Engraved, Dunkin Incised, and Kiam Incised are three of the principal decorated pottery types found in the ceramic assemblage from the ca. A.D. 850-early 1300s Caddo occupation at the George C. Davis site (Story 2000:14).

The ceramic sherds from the 2003 excavations at the George C. Davis site are tempered almost exclusively with grog or crushed sherds (91\%) (see Appendix 2 for detailed analysis of the recovered ceramics). A few of these sherds are from vessels with crushed and burned bone $(9.1 \%)$ or hematite (13.6\%) added to the paste along with grog. Two sherds have no temper and have a sandy paste; however, these do not have coarse sandy textures like the Woodland period Goose Creek Plain, var. unspecified sherds found in low numbers at the site (Story 2000:11-12), and are thus probably from nontempered Caddo vessels.

With respect to how the vessels were fired, an examination of sherd core cross-sections suggest that the majority of the sherds are from vessels that 


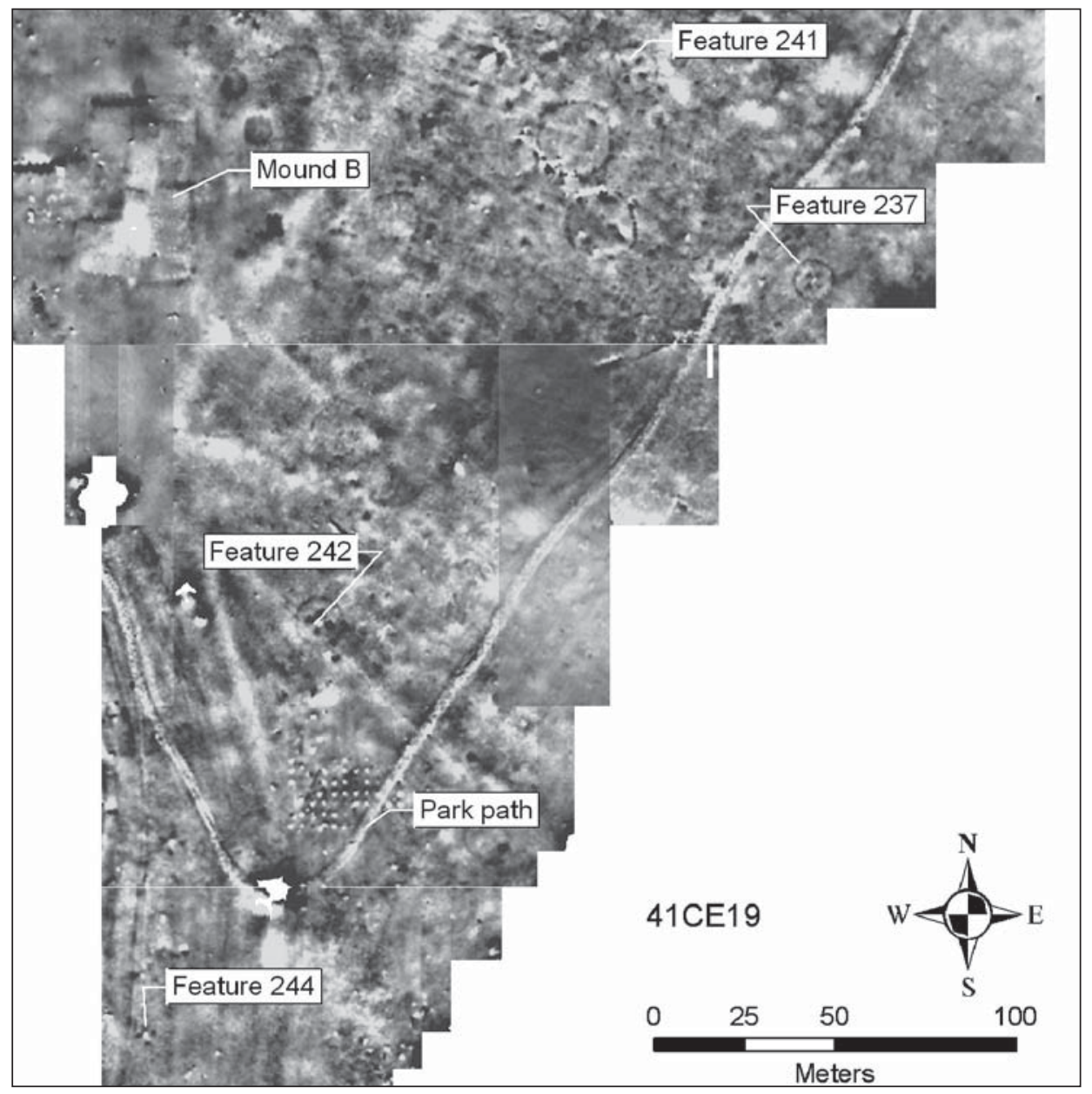

Figure 1. The location of Feature 237 (Unit 113) in the geophysical survey area at the George C. Davis site. This map was provided courtesy of T. Clay Schultz.

were fired in a reducing or low oxygen environment $(63.6 \%)$, but then cooled in the open air (i.e., pulled from the fire to cool). Another $31.8 \%$ are sherds from vessels that were either fired in a high oxygen environment or incompletely oxidized during firing. Only $4.5 \%$ of the sherds are from vessels fired and cooled in a reducing environment.

Less than $15 \%$ of the sherds are from vessels that have been burnished or smoothed on interior and/or exterior vessel surfaces (see Appendix 2). Rather than a true absence of such forms of surface treatment-which are a common feature of both Caddo fine ware and utility wares-their absence here is likely a product of the small size and eroded character of the Unit 113 sherds.

Although the sample of sherds from the Unit 113 excavations is quite small, sherd thickness values range from $6.44 \pm 1.07 \mathrm{~mm}$ for body sherds, 6.8 $\mathrm{mm}$ for the one rim, and $9.3 \mathrm{~mm}$ for the one base sherd. The apparent trend in Caddo vessels for vessel body walls (irrespective of the rims) to increase in thickness from the upper body to the lower body (which is probably the case here), and then the base (which is the thickest part of the vessel), suggests that the Caddo vessels made and used at the George C. Davis site were constructed from the bottom up, with the lower portion of each vessel considerably thicker than the upper part (e.g., Krause 2007:35).

The one chipped stone tool from Unit 113 came from the plow zone. It is a bluish-gray chert (probably from a Central Texas source area) bifaciallychipped tool fragment that is at least $20.4 \mathrm{~mm}$ in length, a maximum of $12.5 \mathrm{~mm}$ in width, and 4.2 $\mathrm{mm}$ in thickness; the bottom of the piece is rounded. There is no evidence of a distinct stem or shaft like the Group I and II perforators found at the site (Baskin 1981:Figure 34), but the Unit 113 piece may be part of a broken perforator. 
Almost $87 \%$ of the lithic debris are from cherts, with the remainder being medium to coarse-grained quartzite pieces (see Appendix 1). Of the cherts, one lustrous gray chert piece (with a rough limestone cortex) may be from a Central Texas source, but the others were probably obtained from stream-worn pebbles in Neches River gravels. The colors of the chert lithic debris pieces are reddish-brown $(n=1)$, brownish-gray $(n=2,100 \%$ cortex $)$, gray $(n=5,20 \%$ cortex), light gray ( $\mathrm{n}=4,25 \%$ cortex $)$, and dark gray $(\mathrm{n}=1)$.

The lithic debris is uniformly small, generally less than $1-2 \mathrm{~cm}$ in length and width, and $33 \%$ have cortex, almost all of which is smooth and streamrolled. The pieces are likely the product of both the reduction of local stream-rolled pebbles to obtain flakes usable for tool manufacture (i.e., arrow points and a variety of flake tools) as well as the resharpening of tools, some of which may not have been made on site by Caddo knappers.

There are two small stream-rolled pebble cores/ chunks of brown chert that have evidence of single flake removals. A third chunk in the artifact assemblage is an unmodified pebble-sized piece of hematite.

The pieces of glauconitic-rich clay are found in the plow zone $(n=1)$ and Feature 237-4 and Feature 237-6. These pieces may be from a concentration of clay collected for use as a pigment. One small piece of burned clay also came from the screened plow zone, while the other was recovered in Feature 237-3. Feature 237-6 had a large fist-sized piece of daub (with stick impressions).

The one remaining artifact is a square cut nail (manufactured between ca. 1820-1890). It was recovered in the screened plow zone of Unit 113.

\section{SUMMARY}

A small sample of prehistoric artifacts from the Unit 113 excavations at the George C. Davis site comprises primarily domestic debris from an Early Caddo (pre-A.D. 1300) occupation (cf. Story 2000). The daub and burned clay found here suggests that the excavations were in an area with some structural burning, and the other artifacts are indicative of ceramic vessel use for cooking and food serving (and then eventual trash discard of broken vessels), while the lithic debris indicates that some tool manufacturing and/or maintenance activities took place in this one locale within the larger prehistoric Caddo village.

\section{REFERENCES CITED}

Baskin, B. A.

1981 Lithic and Mineral Artifacts. In Archeological Investigations at the George C. Davis Site, Cherokee County, Texas: Summers of 1979 and 1980, edited by D. A. Story, pp. 239-320. Occasional Papers No. 1. Texas Archeological Research Laboratory, The University of Texas at Austin.

Creel, D. G., D. Hudler, S. M. Wilson, T. C. Schultz, and C. P. Walker

2005 A Magnetometer Survey of Caddoan Mounds State Historic Site. Technical Report 51. Texas Archeological Research Laboratory, The University of Texas at Austin.

Krause, R. A.

2007 A Potter's Tale. In Plains Village Archaeology: Bison-hunting Farmers in the Central and Northern Plains, edited by S. A. Ahler and M. Kay, pp. 32-40. University of Utah Press, Salt Lake City.

Schultz, T. C.

2010 Architectural Variability in the Caddo Area of Eastern Texas. Ph.D. dissertation, Department of Anthropology, The University of Texas at Austin.

Story, D. A.

2000 Introduction. In The George C. Davis Site, Cherokee County, Texas, by H. P. Newell and A. D. Krieger, pp. 1-31. $2^{\text {nd }}$ Edition. Society for American Archaeology, Washington, D.C.

Suhm, D. A. and E. B. Jelks (editors)

1962 Handbook of Texas Archeology: Type Descriptions. Special Publication No. 1, Texas Archeological Society, and Bulletin No. 4, Texas Memorial Museum, Austin.

Walker, C. P.

2009 Landscape Archaeogeophysics: A Study of Magnetometer Surveys from Etowah (9BW1), The George C. Davis Site (41CE14), and the Hill Farm Site (41BW169). Ph.D. Dissertation, Department of Anthropology, The University of Texas at Austin. 


\section{Appendix 1, Inventory of Artifacts.}

Lot 5378-14, Unit 113, Feature 237-3

1 fist-sized piece of burned clay, no obvious plant impressions

Lot 5378-16, Unit 113, Feature 237-1

1 Holly Fine Engraved body sherd

Lot 5378-18, Unit 113, Feature 237-1

$1 \mathrm{cf}$. Kiam Incised body sherd

Lot 5378-20, Unit 113, Feature 237-1

1 plain body sherd

Lot 5378-49, Unit 113, Feature 237-4

2 pieces of glauconitic-rich clay

Lot 5378-51, Unit 113, Feature 237-6

6 pieces of glauconitic-rich clay

Lot 5378-52, Unit 113, Feature 237-6

1 piece of glauconitic-rich clay

Lot 5378-69, Unit 113, Plow zone

1 piece of burned clay; 17 plain body sherds; 1 cf. Dunkin Incised body sherd; 1 horizontal engraved rim sherd; 1 chert chipped stone tool fragment (possible dart point fragment); 15 pieces of lithic debris; 1 hematite chunk; 2 chert cores/chunks; 1 iron cut nail 
Appendix 2, Detailed Analysis of Plain and Decorated Caddo Ceramic Sherds.

\begin{tabular}{|c|c|c|c|c|c|c|}
\hline Lot No. & $\begin{array}{l}\text { Sherd } \\
\text { Type }\end{array}$ & Temper & $\mathrm{FC}^{*}$ & ST & $\begin{array}{l}\text { Th } \\
(\mathrm{mm})\end{array}$ & Decoration \\
\hline $5378-16$ & body & grog-hematite & $\mathrm{F}$ & $\mathrm{I} / \mathrm{E} \mathrm{B}$ & 6.0 & $\begin{array}{l}\text { fine engraved lines, Holly } \\
\text { Fine Engraved }\end{array}$ \\
\hline $5378-18$ & body & grog & $\mathrm{H}$ & I SM & 9.2 & $\begin{array}{l}\text { 4+ rows of tool punctates; } \\
\text { cf. Kiam Incised }\end{array}$ \\
\hline $5378-20$ & body & grog & $\mathrm{H}$ & - & 7.6 & plain \\
\hline \multirow[t]{19}{*}{$5378-69$} & body & grog-bone & $\mathrm{C}$ & - & 7.2 & $\begin{array}{l}\text { opposed incised lines, cf. } \\
\text { Dunkin Incised }\end{array}$ \\
\hline & $\begin{array}{l}\text { rim, } \\
\text {-Ro }\end{array}$ & grog & G & - & 6.8 & $\begin{array}{l}\text { single horizontal } \\
\text { engraved line }\end{array}$ \\
\hline & body & grog & $\mathrm{G}$ & - & 6.1 & plain \\
\hline & body & none/SP & $\mathrm{E}$ & - & 5.3 & plain \\
\hline & body & grog & B & - & 6.0 & plain \\
\hline & body & none/SP & $\mathrm{E}$ & - & 5.4 & plain \\
\hline & body & grog & G & - & 5.0 & plain \\
\hline & body & grog-hematite & A & - & 6.8 & plain \\
\hline & body & grog & G & - & 6.6 & plain \\
\hline & body & grog & G & - & 5.9 & plain \\
\hline & body & grog/SP & $\mathrm{F}$ & - & 6.9 & plain \\
\hline & body & grog-bone & G & E B & 4.3 & plain \\
\hline & body & grog & G & - & 7.3 & plain \\
\hline & body & grog-hematite & $\mathrm{F}$ & - & 7.2 & plain \\
\hline & body & grog & $\mathrm{G}$ & - & 8.1 & plain \\
\hline & body & grog & A & I SM & 8.2 & plain \\
\hline & body & grog/SP & $\mathrm{D}$ & - & 5.2 & plain \\
\hline & body & grog & G & - & 4.6 & plain \\
\hline & body & grog & A & - & 9.3 & plain \\
\hline
\end{tabular}

*FC=firing conditions; $\mathrm{A}=$ oxidizing environment; $\mathrm{B}=$ =reducing environment; $\mathrm{C}-\mathrm{E}$, incompletely oxidized;

$\mathrm{F}-\mathrm{H}=$ reducing environment, but cooled in the open air

$\mathrm{ST}=$ surface treatment; $\mathrm{I}=$ interior; $\mathrm{E}=$ =xterior; $\mathrm{B}=$ burnished; $\mathrm{SM}=$ smoothed

$\mathrm{SP}=$ sandy paste; $\_$- Ro=rim form indeterminate, lip is rounded

Th=thickness 